\title{
Volunteer Glyphosate and Glufosinate Resistant Corn Competitiveness and Control in Glyphosate and Glufosinate Resistant Corn
}

\author{
Nader Soltani, Christy Shropshire, Peter H. Sikkema \\ University of Guelph, Ridgetown Campus, Ridgetown, Canada \\ Email: soltanin@uoguelph.ca
}

Received 18 January 2014; revised 15 March 2014; accepted 2 April 2014

Copyright (C) 2014 by authors and Scientific Research Publishing Inc.

This work is licensed under the Creative Commons Attribution International License (CC BY). http://creativecommons.org/licenses/by/4.0/

\section{Abstract}

Glyphosate and glufosinate resistant (RR/LL) volunteer corn has become a problem when hybrid RR/LL corn follows hybrid RR/LL corn in the rotation. A total of six field trials were conducted over a three-year period (2008 to 2010) in southwestern Ontario to 1) evaluate the competitiveness of volunteer RR/LL corn in hybrid RR/LL corn, and 2) determine how to control volunteer RR/LL corn in hybrid RR/LL corn. The predicted volunteer RR/LL corn density to reduce hybrid RR/LL corn yield by $5 \%$ was 1.7 volunteer RR/LL corn plants $\mathbf{m}^{-2}$. There was no crop injury in hybrid RR/LL corn with herbicides evaluated at 1 and 2 WAA except for rimsulfuron(15 g-ai-ha-1) and foramsulfuron (35 g-ai·ha-1) which caused as much as $5 \%$ and $11 \%$ injury in hybrid RR/LL corn, respectively. Glyphosate $\left(1800 \mathrm{~g} \cdot \mathrm{ae} \cdot \mathrm{ha}^{-1}\right)$, glufosinate(500 g.ae $\left.\cdot \mathrm{ha}^{-1}\right)$ and glyphosate + glufosinate $\left(1800+500 \mathrm{~g} \cdot \mathrm{ae} \cdot \mathrm{ha}^{-1}\right)$ provided up to $18 \%, 10 \%$ and $21 \%$ control of volunteer RR/LL

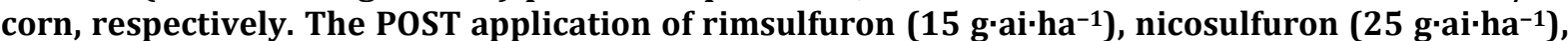
nicosulfuron/rimsulfuron (25 g·ai·ha-1), foramsulfuron (35 g·ai·ha ${ }^{-1}$ ), and primisulfuron/dicamba (166 $\mathrm{g} \cdot \mathrm{ai}^{\mathrm{h}} \mathrm{ha}^{-1}$ ) did not provided any control of volunteer RR/LL corn. Glyphosate and glyphosate + glufosinate reduced volunteer corn density $26 \%$ and $30 \%$, respectively. The other herbicides evaluated did not reduce volunteer RR/LL corn density compared to the weedy control. None of the herbicides evaluated reduced volunteer RR/LL corn cob numbers compared to the weedy control. Glyphosate + glufosinate applied POST reduced volunteer RR/LL corn yield 35\% compared to the weedy control but other herbicides evaluated caused no reduction in volunteer RR/LL corn yield compared to the weedy control. Glyphosate applied POST resulted in hybrid RR/LL corn yield equivalent to the weed free control but all other herbicide treatments resulted hybrid RR/LL corn yield equivalent to the weedy control. This research concludes that volunteer RR/LL corn can be very competitive with RR/LL hybrid corn. None of the herbicides evaluated provided adequate control of volunteer RR/LL corn in hybrid RR/LL corn. 


\section{Keywords}

\section{Crop Injury, Competitiveness, Control, Density, Yield, Zea mays}

\section{Introduction}

Corn (Zea mays L.) production is important to agriculture and the economy of Ontario where annually 9.2 million tonnes of grain corn is produced on approximately 894,000 hectares compromising over $60 \%$ of Canada's total corn production with a farm-gate value of $\$ 2.4$ billion [1]. Most of the corn grown in Ontario is resistant to both glyphosate and glufosinate (RR/LL) which has provided growers with additional weed management options that provide broad spectrum weed control, have a wide margin of crop safety thereby resulting higher net returns [2] [3].

Glyphosate-resistant corn was first introduced in Canada in 2001 and the market share has increased steadily over the years. In 2013, about 95\% of the corn hectarage in Eastern Canada was planted to glyphosate-resistant corn and the percentage is expected to increase in the future [3]. With the increase of hybrid RR/LL corn production, volunteer RR/LL corn (Zea mays) has become a major problem whenever hybrid RR/LL corn follows hybrid RR/LL corn in the rotation since glyphosate or glufosinate do not control volunteer RR/LL corn from corn grown the previous year. Volunteer corn seeds are mainly as result of stalk lodging or breakage; dropped ears, kernel losses, and combine head shatter losses of very dry grain the previous year and can be significant in fields affected by storm damage, diseases, insects, and various environmental stresses [4]. Volunteer RR/LL corn in hybrid RR/LL corn competes for moisture, nutrients and light, reduces hybrid RR/LL corn yield, harvest efficiency and grain quality and can increase disease incidence [5]-[10].

Studies have shown that early weed interference in corn can result in decreased leaf emergence, reduced leaf area and lower corn grain yield [11]-[13]. Leaf tip emergence, crop growth rate and yield have been shown to be effected by weed competition in hybrid corn [14]. Control of volunteer corn in hybrid corn is difficult as most hybrids used by growers in Ontario are stacked with resistance traits to both glyphosate and glufosinate, therefore, glyphosate or glufosinate do not adequately control volunteer RR/LL corn in hybrid RR/LL corn in the following year [4]. Therefore, it is critical to develop new weed management strategies to control volunteer RR/LL corn in hybrid RR/LL corn.

Limited published information is available on the competitive effects of volunteer RR/LL corn in hybrid RR/LL corn and strategies for the control of volunteer RR/LL corn in hybrid RR/LL corn under Ontario growing conditions. Growers need herbicide options that are safe, efficacious and economically sustainable to control volunteer RR/LL corn in hybrid RR/LL corn to be competitive in the global market.

The objectives of this study were to determine the competitive effects of volunteer RR/LL corn in hybrid RR/LL corn and to evaluate glyphosate, glufosinate, glyphosate + glufosinate, rimsulfuron, nicosulfuron, nicosulfuron/rimsulfuron, foramsulfuron, and primisulfuron/dicamba applied postemergence (POST) for the control of volunteer RR/LL corn in hybrid RR/LL corn.

\section{Materials and Methods}

\subsection{Study Establishment}

Six field trials ( 3 for competiveness and 3 for volunteer control control) were conducted over a three year period (2008 to 2010) at the University of Guelph Ridgetown Campus in southwestern Ontario. The soil at Ridgetown is a Watford (Grey to Brown Brunisolic)-Brady (Gleyed Brunisolic Grey to Brown Luvisol, mixed) sandy clay loam with $53 \%$ sand, $27 \%$ silt, $20 \%$ clay, $5.3 \%$ organic matter and a pH of 7.0 in $2008,56 \%$ sand, $27 \%$ silt, $17 \%$ clay, $5.4 \%$ organic matter and a pH of 6.7 in 2009 , and $52 \%$ sand, $28 \%$ silt, $20 \%$ clay, $5.9 \%$ organic matter and a pH of 6.4 in 2010. Seedbed preparation consisted of fall moldboard plowing followed by three passes with a field cultivator with rolling basket harrows in the spring.

\subsection{Competitiveness Studies}

The experimental design was a randomized complete block design (RCBD) with four replications. Plots were 3 
$\mathrm{m}$ wide (four rows spaced $0.75 \mathrm{~m}$ apart) and $8 \mathrm{~m}$ long. Each plot consisted of four rows of 4 rows of "DKC50-45 RR" corn. Hybrid RR/LL corn was planted in late April to early May of each year at a rate of 80,000 seeds ha $^{-1}$. The glyphosate-resistant volunteer corn seed used to establish the experiments was from glyphosate-resistant "DKC50-45 RR" corn grown the previous year from a commercial field in Ontario. The corn seed was spread prior to seeding the hybrid corn at approximately 7500, 15,000, 30,000, 45,000, 60,000, and 75,000 volunteer seeds $\cdot$ ha $^{-1}$ using a broadcast fertilizer spreader and tilled into the soil with two passes of a cultivator with rolling basket harrows.

At 4, 8 and 12 week after emergence (WAE), volunteer corn density, hybrid corn height, leaf collars and leaf tips were determined. All variables involving hybrid corn (height, leaf collars, leaf tips, and yield) were converted to a percent of the weed-free check. Volunteer RR/LL corn was hand harvested prior to hybrid RR/LL corn harvest. Number of cobs and yield for volunteer RR/LL corn were recorded. Hybrid RR/LL corn was harvested with small plot combine and moisture content and yield were recorded.

PROC MIXED procedures of SAS 9.2 (SAS Institute Inc. 2008) was used to determine which environments could be combined for regression analysis (data combined, if the environment by rate interaction was not significant). All three environments could be combined for each variable.

\subsubsection{Regression Equations (Models) Used}

Parameters were regressed against volunteer RR/LL corn density at the corresponding timing, designated as DENS in the equations.

Hybrid RR/LL corn height, leaf collars, leaf tips and yield; predicted values for volunteer RR/LL corn cob number and yield (linear):

$$
[1] \mathrm{Y}=\mathrm{a} 0+\mathrm{b} 1 * \text { DENS }
$$

where $\mathrm{a} 0$ is the intercept and $\mathrm{b} 1$ is the slope.

\subsubsection{Predicted Values}

Regression equations were used to calculate predicted volunteer RR/LL corn densities (per $\mathrm{m}^{2}$ ) that resulted in a $5 \%$ reduction $\left(\mathrm{R}_{95}\right)$ of hybrid RR/LL corn height, leaf collars, leaf tips and yield.

If the predicted volunteer corn density was higher than the highest volunteer corn density (Table 1, Table 2) then it was expressed as ">” because it would not be proper to extrapolate outside the range of densities evaluated in these experiments.

The $R_{95}$ value was also used to calculate the predicted volunteer cob number and yield at that volunteer RR/LL corn density.

\subsection{Volunteer Corn Control Studies}

The experimental design was a randomized complete block design (RCBD) with four replications. Treatments

Table 1. Target and actual volunteer corn densities at 4, 8 and 12 WAE for Ridgetown 2008-2010. ${ }^{\text {a }}$

\begin{tabular}{|c|c|c|c|c|c|c|c|c|c|}
\hline \multirow[b]{3}{*}{$\begin{array}{l}\text { Target volunteer } \\
\text { corn density }\end{array}$} & \multicolumn{9}{|c|}{ Volunteer corn density } \\
\hline & \multicolumn{3}{|c|}{2008} & \multicolumn{3}{|c|}{2009} & \multicolumn{3}{|c|}{2010} \\
\hline & $4 \mathrm{WAE}$ & $8 \mathrm{WAE}$ & $12 \mathrm{WAE}$ & $4 \mathrm{WAE}$ & $8 \mathrm{WAE}$ & $12 \mathrm{WAE}$ & $4 \mathrm{WAE}$ & $8 \mathrm{WAE}$ & $12 \mathrm{WAE}$ \\
\hline \multicolumn{10}{|c|}{ plants $\cdot \mathrm{m}^{-2}$} \\
\hline 0.75 & 0.3 & 0.4 & 0.3 & 0.5 & 0.4 & 0.3 & 0.3 & 0.3 & 0.3 \\
\hline 1.5 & 0.5 & 0.6 & 0.6 & 0.8 & 0.9 & 0.8 & 0.8 & 1.1 & 0.8 \\
\hline 3 & 1.2 & 1.2 & 1.2 & 1.6 & 1.5 & 1.4 & 1.6 & 1.7 & 1.4 \\
\hline 4.5 & 1.5 & 1.6 & 1.4 & 2.5 & 2.3 & 2.2 & 1.7 & 1.3 & 1.4 \\
\hline 6 & 2.3 & 2.5 & 2.2 & 3.3 & 3.0 & 2.9 & 2.7 & 1.9 & 2.0 \\
\hline 7.5 & 2.7 & 2.8 & 2.6 & 4.2 & 4.0 & 3.7 & 3.0 & 2.6 & 2.5 \\
\hline
\end{tabular}

a Abbreviations: WAE, weeks after hybrid corn emergence. 
Table 2. Regression parameter estimates and predicted volunteer corn density, cob number and yield from regression models of hybrid corn height, leaf collars, leaf tips and yield. ${ }^{a}$

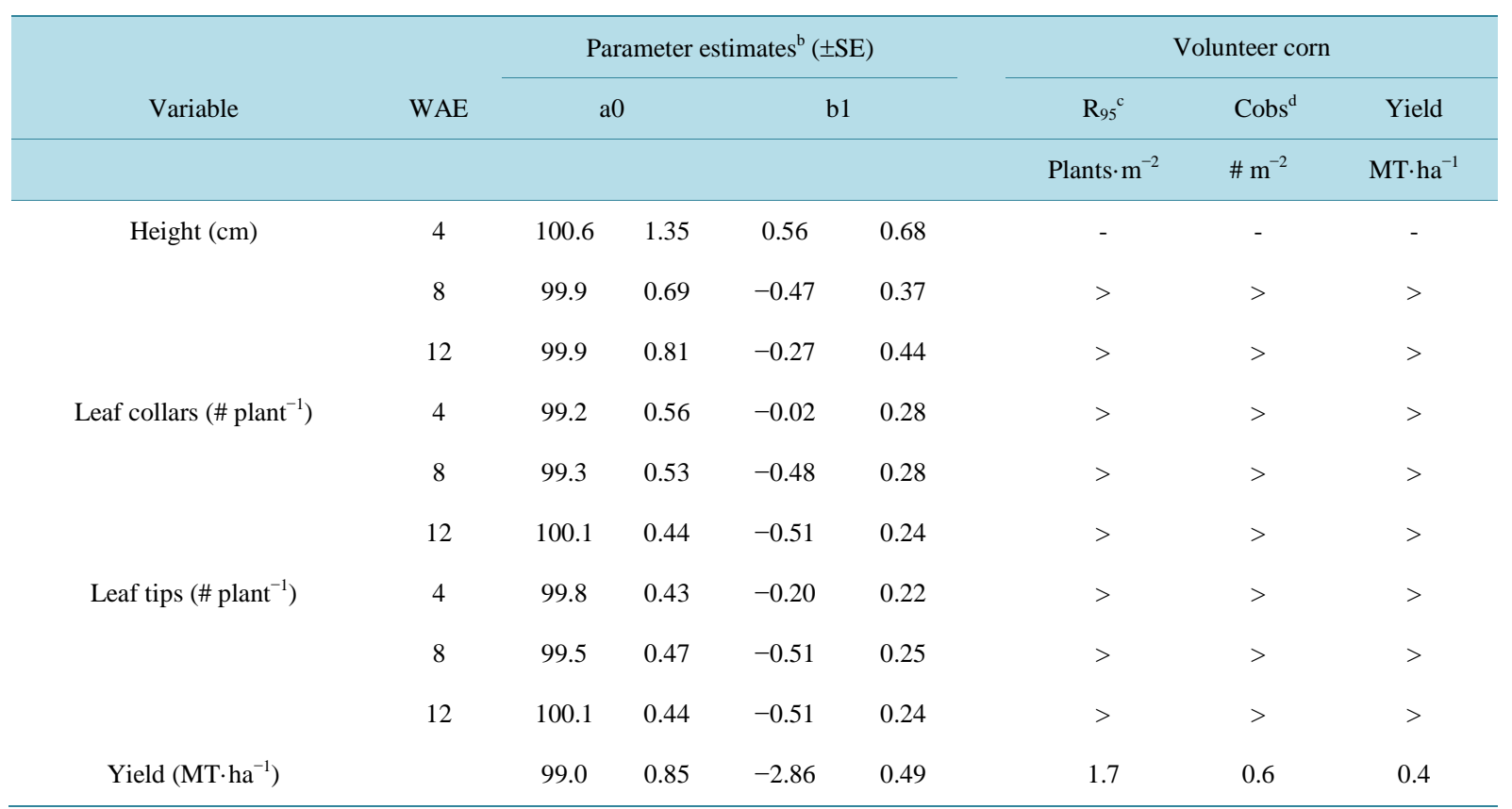

> denotes a predicted volunteer corn density, cob number or yield outside the range evaluated in these experiments. ${ }^{\mathrm{a}} \mathrm{Abbreviations:} \mathrm{WAE,} \mathrm{weeks} \mathrm{after}$ hybrid corn emergence. ${ }^{b}$ Linear parameters (Equation (1)): a0, intercept; b1, slope. ${ }^{c} \mathrm{R}_{95}$ is the volunteer corn density at which a given variable is reduced by $5 \%$. ${ }^{\mathrm{d}}$ The number of cobs predicted for the corresponding $\mathrm{R}_{95}$ density.

consisted of glyphosate $\left(1800 \mathrm{~g} \cdot \mathrm{ae}^{-} \mathrm{ha}^{-1}\right)$, glufosinate $\left(500 \mathrm{~g} \cdot \mathrm{ae} \cdot \mathrm{ha}{ }^{-1}\right)$, glyphosate + glufosinate $(1800+500$ $\left.\mathrm{g} \cdot \mathrm{ae} \cdot \mathrm{ha}^{-1}\right)$, rimsulfuron $\left(15 \mathrm{~g} \cdot \mathrm{ai} \cdot \mathrm{ha}^{-1}\right)$, nicosulfuron $\left(25 \mathrm{~g} \cdot \mathrm{ai}^{\mathrm{h}} \mathrm{ha}^{-1}\right)$, nicosulfuron/rimsulfuron $\left(25 \mathrm{~g} \cdot \mathrm{ai} \cdot \mathrm{ha}^{-1}\right)$, foramsulfuron $\left(35 \mathrm{~g} \cdot \mathrm{ai} \cdot \mathrm{ha}^{-1}\right)$, and primisulfuron/dicamba $\left(166 \mathrm{~g} \cdot \mathrm{ai} \cdot \mathrm{ha}^{-1}\right)$ All treatments except primisulfuron/ dicamba included dicamba (141 g·ai·ha $\left.{ }^{-1}\right)$. Rimsulfuron, nicosulfuron, nicosulfuron/rimsulfuron, and primisulfuron/dicamba treatments included a non-ionic surfactant (Agaral $90^{\circledR}$ ) at $0.2 \% \mathrm{v} / \mathrm{v}$. Foramsulfuron treatment in-

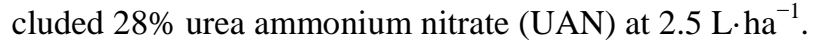

Plots were $3 \mathrm{~m}$ wide and $8 \mathrm{~m}$ long. Each plot consisted of four rows of "DKC50-45 RR" corn spaced $0.75 \mathrm{~m}$ apart. Hybrid RR/LL corn was planted in late April to early May of each year at a rate of 80,000 seeds· ha ${ }^{-1}$. The volunteer RR/LL corn seed used to establish the experiments was from "DKC50-45 RR" RR/LL corn grown the previous year from a commercial field in Ontario. The volunteer RR/LL corn seed was spread prior to seeding hybrid RR/LL corn using a broadcast fertilizer spreader and tilled into the soil with two passes of a cultivator with rolling basket harrows.

Herbicide applications were made with a $\mathrm{CO}_{2}$-pressurized backpack sprayer calibrated to deliver $200 \mathrm{~L} \cdot \mathrm{ha}^{-1}$ of water at $207 \mathrm{kPa}$ through four Hypro Ultra-low drift 120-02 nozzles (Hypro, New Brighton, MN 55112) spaced $50 \mathrm{~cm}$ apart. Herbicide applications were made when the volunteer RR/LL corn was up to $15 \mathrm{~cm}$ in height.

Hybrid RR/LL corn injury was rated visually 1 and 2 weeks after application (WAA), and volunteer RR/LL corn control was rated visually 2, 4 and 8 WAA on a scale of $0 \%$ to $100 \%$. A rating of 0 was defined as no visible hybrid RR/LL corn injury, and a rating of 100 was defined as total corn necrosis. At 8 WAA volunteer RR/LL corn density and at 16 WAT volunteer RR/LL corn cob number and yield in each plot was determined. Yield for the hybrid RR/LL corn was measured at crop maturity by harvesting the middle two rows of each plot with a plot combine. All corn yields were adjusted to 15.5\% moisture.

All data were subjected to analysis of variance (ANOVA) and were combined over experiments and years and analysed using the PROC MIXED procedure of SAS. Weedy and weed free checks were not included in analysis of injury. The weedy check was not included in the analysis of volunteer RR/LL corn control and weed free check was not included in the analysis of volunteer RR/LL corn density, cobs or yield. However, all values were compared independently to zero to evaluate treatment differences with the weedy/weed free check. Environment 
by treatment interaction was significant for all injury ratings. All other variables could be combined across the three environments. Injury data at 1 WAA in 2008 and 2009 were all zero and could not be combined with 2010 (log transformed). Injury data at 2 WAA in 2008 and 2009 were all zero and could not be combined with 2010 (no transformation). To meet assumptions of normality, volunteer RR/LL corn control 4 and 8 WAA were arcsine square root transformed for analysis, and back-transformed for presentation of results. All other variables did not need transformation. Treatment means were separated using Fisher's protected LSD at $\mathrm{P}<0.05$.

\section{Results and Discussions}

\subsection{Competitiveness Studies}

Volunteer RR/LL corn densities varied between years (Table 1). Actual volunteer corn densities ranged from 0.3 to 4.0 plants $\cdot \mathrm{m}^{-2}$ depending on the year and WAE (4, 8, and $12 \mathrm{WAE}$ ) for the targeted seeding rates (Table 1). The predicted volunteer corn density to reduce hybrid corn height, leaf collars (\# plant ${ }^{-1}$ ) and leaf tips (\# plant $^{-1}$ ) by $5 \%$ was greater than the range of volunteer corn densities established in these experiments (Table 2). The predicted volunteer corn density to reduce hybrid corn yield $5 \%$ was 1.7 volunteer corn plants $\cdot \mathrm{m}^{-2}, 0.6$ volunteer corn cobs $\cdot \mathrm{m}^{-2}$, and $0.4 \mathrm{MT} \cdot \mathrm{ha}^{-1}$ volunteer corn yield (Table 2). Alms et al. (2007) in South Dakota, USA studied the effects of volunteer corn densities of 0, 0.2, 0.8, 1.2, 1.9, 2.5, 2.7, or 3.5 plants $\cdot \mathrm{m}^{-2}$ in Dekalb DKC 46 - 60 VT3 corn and reported 0\% - 13\% hybrid corn yield loss or $0 \%$ - 9\% yield loss when accounting for corn grain produced by volunteer corn. However, volunteer corn at the same density reduced RR soybean yield $0 \%-54 \%$ indicating that volunteer corn is more competitive in soybean than in corn [15]. Wilson et al. [16] in Nebraska, USA reported $2 \%$ corn yield loss from a volunteer corn density of 1.4 plants $\cdot \mathrm{m}^{-2}$ and $10 \%$ corn yield loss from a volunteer corn density of 2.8 plants $\cdot \mathrm{m}^{-2}$. In contrast, soybean yield was reduced $10 \%$ and $27 \%$ at volunteer corn density of 1.4 and 2.8 plants $\mathrm{m}^{-2}$, respectively [16]. Stahl and Coulter [17] in Minnesota, USA studying volunteer corn densities at the rate of 1.6 to 14.5 plants $\cdot \mathrm{m}^{-2}$ also found a reduction of $26 \%$ in the yield of hybrid corn. Stahl and Coulter [17] found that volunteer corn density had to reach 3.2 plants $\cdot \mathrm{m}^{-2}$ before hybrid corn yield was reduced $18 \%$ on average. They also concluded that the volunteer corn growth lagged one to 6 leaf stages behind the hybrid corn and was unlikely to offset hybrid corn yield losses as ears were too small (at high density) at the harvest time [4] [17].

\subsection{Volunteer Corn Control Studies}

There was no crop injury in hybrid RR/LL corn with the herbicides evaluated at 1 and 2 WAA except for rimsulfuron and foramsulfuron which caused as much as 5 and $11 \%$ crop injury in hybrid corn, respectively (Table 3). Glyphosate $\left(1800 \mathrm{~g} \cdot \mathrm{ae}^{\mathrm{h}} \mathrm{ha}^{-1}\right)$, glufosinate $\left(500 \mathrm{~g} \cdot \mathrm{ae} \cdot \mathrm{ha}^{-1}\right)$ and glyphosate + glufosinate $\left(1800+500 \mathrm{~g} \cdot \mathrm{ae}^{\mathrm{h}} \cdot \mathrm{ha}^{-1}\right)$ provided $15 \%-18 \%, 6 \%-10 \%$ and $16 \%-21 \%$ control of volunteer RR/LL corn at 1, 2, 4, and 8 WAA, respectively (Table 3). Rimsulfuron ( $\left(15 \mathrm{~g} \cdot \mathrm{ai} \cdot \mathrm{ha}^{-1}\right)$, nicosulfuron $\left(25 \mathrm{~g} \cdot \mathrm{ai} \cdot \mathrm{ha}^{-1}\right)$, nicosulfuron/rimsulfuron $\left(25 \mathrm{~g} \cdot \mathrm{ai} \cdot \mathrm{ha}^{-1}\right)$, foramsulfuron (70 g.ai $\left.\cdot \mathrm{ha}^{-1}\right)$, and primisulfuron/dicamba $\left(166 \mathrm{~g} \cdot \mathrm{ai} \cdot \mathrm{ha}^{-1}\right)$ did not provide any control of volunteer RR/LL corn at the rates evaluated.

Glyphosate $\left(1800 \mathrm{~g} \cdot \mathrm{ae} \cdot \mathrm{ha}^{-1}\right)$ and glyphosate + glufosinate $\left(1800+500 \mathrm{~g} \cdot \mathrm{ae} \cdot \mathrm{ha}^{-1}\right)$ reduced volunteer corn density $26 \%$ and $30 \%$, respectively. However, glufosinate $\left(500 \mathrm{~g} \cdot \mathrm{ae} \cdot \mathrm{ha}^{-1}\right)$, rimsulfuron $\left(15 \mathrm{~g} \cdot \mathrm{ai} \cdot \mathrm{ha}^{-1}\right)$, nicosulfuron $\left(25 \mathrm{~g} \cdot \mathrm{ai} \cdot \mathrm{ha}^{-1}\right)$, nicosulfuron/rimsulfuron $\left(25 \mathrm{~g} \cdot \mathrm{ai} \cdot \mathrm{ha}^{-1}\right)$, foramsulfuron $\left(70 \mathrm{~g} \cdot \mathrm{ai} \cdot \mathrm{ha}^{-1}\right)$, and primisulfuron/dicamba (166 $\mathrm{g} \cdot \mathrm{ai} \cdot \mathrm{ha}^{-1}$ ) caused no reduction in volunteer corn density compared to the weedy control (Table 4).

None of the herbicides evaluated reduced volunteer corn cob numbers compared to the weedy control (Table 4). Glyphosate + glufosinate reduced volunteer RR/LL corn yield 35\% compared to the weedy control but glyphosate, glufosinate, rimsulfuron, nicosulfuron, nicosulfuron/rimsulfuron, foramsulfuron, and primisulfuron/ dicamba caused no reduction in volunteer corn yield compared to the weedy control (Table 4).

Yield of hybrid RR/LL corn was similar to weedy control with glyphosate $\left(1800 \mathrm{~g} \cdot \mathrm{ae} \cdot \mathrm{ha} \mathrm{h}^{-1}\right)$, glufosinate (500 $\left.\mathrm{g} \cdot \mathrm{ae} \cdot \mathrm{ha}^{-1}\right)$, glyphosate + glufosinate $\left(1800+500 \mathrm{~g} \cdot \mathrm{ae} \cdot \mathrm{ha}^{-1}\right)$, rimsulfuron $\left(15 \mathrm{~g} \cdot \mathrm{ai} \cdot \mathrm{ha}{ }^{-1}\right)$, nicosulfuron (25 $\left.\mathrm{g} \cdot \mathrm{ai} \cdot \mathrm{ha} \mathrm{a}^{-1}\right)$, nicosulfuron/rimsulfuron $\left(25 \mathrm{~g} \cdot \mathrm{a} \cdot \mathrm{ha}^{-1}\right)$, foramsulfuron $\left(70 \mathrm{~g} \cdot \mathrm{ai} \cdot \mathrm{ha}^{-1}\right)$, and primisulfuron/dicamba $\left(166 \mathrm{~g} \cdot \mathrm{ai}^{\mathrm{h}} \mathrm{ha}^{-1}\right)$. All herbicides evaluated except glyphosate had lower yield than weed free control (Table 4). In other studies, Alms et al. [15] found effective control of volunteer RR volunteer corn at a density of 3.5 plant $\cdot \mathrm{m}^{-2}$ with glufosinate applied POST at $470 \mathrm{~g} \cdot \mathrm{ae} \cdot \mathrm{ha}^{-1}$ in RR hybrid corn. 
Table 3. Visual estimates of hybrid corn injury 1 and 2 WAA and volunteer corn control 1, 2, 4 and 8 WAA with various herbicide treatments. Means followed by the same letter within a column are not significantly different according to Fisher's Protected LSD at $\mathrm{P}<0.05$. $^{\mathrm{a}}$

\begin{tabular}{|c|c|c|c|c|c|c|c|}
\hline \multirow[b]{2}{*}{ Treatment $^{\mathrm{b}}$} & \multirow[b]{2}{*}{ Rate } & \multicolumn{2}{|c|}{ Crop injury } & \multicolumn{4}{|c|}{ Volunteer corn control } \\
\hline & & $1 \mathrm{WAA}$ & 2 WAA & $1 \mathrm{WAA}$ & 2 WAA & 4 WAA & 8 WAA \\
\hline & $\mathrm{g} \cdot \mathrm{ai} \cdot \mathrm{ha}^{-1}$ & & & $\%$ & & & \\
\hline Weedy control & & $0 \mathrm{a}$ & $0 \mathrm{a}$ & $0 \mathrm{~d}$ & $0 \mathrm{~d}$ & $0 \mathrm{~d}$ & $0 \mathrm{~d}$ \\
\hline Weed free control & & $0 \mathrm{a}$ & $0 \mathrm{a}$ & $100 \mathrm{a}$ & $100 \mathrm{a}$ & $100 \mathrm{a}$ & $100 \mathrm{a}$ \\
\hline Glyphosate & 1800 & $0 \mathrm{a}$ & $0 \mathrm{a}$ & $16 \mathrm{~b}$ & $18 \mathrm{~b}$ & $17 \mathrm{~b}$ & $15 \mathrm{~b}$ \\
\hline Glufosinate & 500 & $0 \mathrm{a}$ & $0 \mathrm{a}$ & $7 \mathrm{c}$ & $10 \mathrm{c}$ & $7 \mathrm{c}$ & $6 \mathrm{c}$ \\
\hline Glyphosate + glufosinate & $1800+500$ & $0 \mathrm{a}$ & $0 \mathrm{a}$ & $21 \mathrm{~b}$ & $21 \mathrm{~b}$ & $17 \mathrm{~b}$ & $16 \mathrm{~b}$ \\
\hline Rimsulfuron $^{c}$ & 15 & $5 b$ & $0 \mathrm{a}$ & $0 \mathrm{~d}$ & $0 \mathrm{~d}$ & $0 \mathrm{~d}$ & $0 \mathrm{~d}$ \\
\hline Nicosulfuron $^{c}$ & 25 & $0 \mathrm{a}$ & $0 \mathrm{a}$ & $0 \mathrm{~d}$ & $0 \mathrm{~d}$ & $0 \mathrm{~d}$ & $0 \mathrm{~d}$ \\
\hline Nicosulfuron/rimsulfuron ${ }^{c}$ & 25 & $0 \mathrm{a}$ & $0 \mathrm{a}$ & $0 \mathrm{~d}$ & $0 \mathrm{~d}$ & $0 \mathrm{~d}$ & $0 \mathrm{~d}$ \\
\hline Foramsulfuron $^{\mathrm{d}}$ & 35 & $11 \mathrm{c}$ & $4 \mathrm{~b}$ & $0 \mathrm{~d}$ & $0 \mathrm{~d}$ & $0 \mathrm{~d}$ & $0 \mathrm{~d}$ \\
\hline Primisulfuron/dicamba ${ }^{c}$ & 166 & $0 \mathrm{a}$ & $0 \mathrm{a}$ & $0 \mathrm{~d}$ & $0 \mathrm{~d}$ & $0 \mathrm{~d}$ & $0 \mathrm{~d}$ \\
\hline SE & & 1 & 0 & 3 & 3 & 3 & 3 \\
\hline
\end{tabular}

${ }^{\mathrm{a}}$ Abbreviations: WAA, weeks after application. ${ }^{\mathrm{b}}$ All treatments except primisulfuron/dicamba included dicamba $\left(141 \mathrm{~g} \cdot \mathrm{ai} \cdot \mathrm{ha}{ }^{-1}\right) .{ }^{\mathrm{c}}$ Included non-ionic surfactant $(0.2 \% \mathrm{v} / \mathrm{v}) .{ }^{\mathrm{d}}$ Included $28 \%$ UAN $\left(2.5 \mathrm{~L} \cdot \mathrm{ha}^{-1}\right)$.

Table 4. Density, number of cobs and yield for volunteer corn, and yield for hybrid corn with various herbicide treatments. Means followed by the same letter within a column are not significantly different according to Fisher's Protected LSD at P < 0.05 .

\begin{tabular}{|c|c|c|c|c|c|}
\hline \multirow[b]{2}{*}{ Treatment $^{\mathrm{a}}$} & \multirow[b]{2}{*}{ Rate } & \multicolumn{3}{|c|}{ Volunteer corn } & \multirow{2}{*}{ Hybrid corn yield } \\
\hline & & Density & Cobs & Yield & \\
\hline & $g \cdot a i \cdot h a^{-1}$ & $\# \mathrm{~m}^{-2}$ & $\# \mathrm{~m}^{-2}$ & MT $\cdot \mathrm{ha}^{-1}$ & MT $\cdot \mathrm{ha}^{-1}$ \\
\hline Weedy control & & $2.3 \mathrm{~cd}$ & $1.1 \mathrm{a}$ & $0.74 \mathrm{bc}$ & $14.2 \mathrm{~b}$ \\
\hline Weed free control & & $0 \mathrm{a}$ & $0 \mathrm{a}$ & $0 \mathrm{a}$ & $15.8 \mathrm{a}$ \\
\hline Glyphosate & 1800 & $1.7 \mathrm{~b}$ & $0.8 \mathrm{a}$ & $0.58 \mathrm{ab}$ & $15.1 \mathrm{ab}$ \\
\hline Glufosinate & 500 & $2.2 \mathrm{c}$ & $1.0 \mathrm{a}$ & $0.66 \mathrm{abc}$ & $14.7 \mathrm{~b}$ \\
\hline Glyphosate + glufosinate & $1800+500$ & $1.6 \mathrm{~b}$ & $0.7 \mathrm{a}$ & $0.48 \mathrm{a}$ & $14.7 \mathrm{~b}$ \\
\hline Rimsulfuron $^{\mathrm{b}}$ & 15 & $2.6 \mathrm{~d}$ & $1.0 \mathrm{a}$ & $0.67 \mathrm{bc}$ & $14.6 \mathrm{~b}$ \\
\hline Nicosulfuron ${ }^{c}$ & 25 & $2.4 \mathrm{~cd}$ & $1.0 \mathrm{a}$ & $0.73 \mathrm{bc}$ & $14.6 \mathrm{~b}$ \\
\hline Nicosulfuron/rimsulfuron ${ }^{c}$ & 25 & $2.4 \mathrm{~cd}$ & $1.1 \mathrm{a}$ & $0.75 \mathrm{bc}$ & $14.4 \mathrm{~b}$ \\
\hline Foramsulfuron ${ }^{\mathrm{c}}$ & 70 & $2.3 \mathrm{~cd}$ & $0.9 \mathrm{a}$ & $0.62 \mathrm{abc}$ & $14.4 \mathrm{~b}$ \\
\hline Primisulfuron/dicamba ${ }^{c}$ & 166 & $2.4 \mathrm{~cd}$ & $1.1 \mathrm{a}$ & $0.81 \mathrm{c}$ & $14.3 \mathrm{~b}$ \\
\hline SE & & 0.1 & 0.1 & 0.04 & 0.1 \\
\hline
\end{tabular}

${ }^{\mathrm{a}}$ All treatments except primisulfuron/dicamba included dicamba (141 $\left.\mathrm{g} \cdot \mathrm{ai} \cdot \mathrm{ha}{ }^{-1}\right)$. ${ }^{\mathrm{b}}$ Included non-ionic surfactant $(0.2 \% \mathrm{v} / \mathrm{v}) .{ }^{\mathrm{c}}$ Included $28 \%$ UAN (2.5 $\left.\mathrm{L} \cdot \mathrm{ha}^{-1}\right)$. 


\section{Conclusion}

This research concludes that competition from volunteer RR/LL corn can alter the growth and reduce the yield of hybrid RR/LL corn. Postemergence application of glyphosate (1800 g·ae $\left.\mathrm{ha}^{-1}\right)$, glufosinate $\left(500 \mathrm{~g} \cdot \mathrm{ae} \cdot \mathrm{ha}^{-1}\right)$, glyphosate + glufosinate $\left(1800+500 \mathrm{~g} \cdot \mathrm{ae} \cdot \mathrm{ha}^{-1}\right)$, rimsulfuron $\left(15 \mathrm{~g} \cdot \mathrm{ai}^{\circ} \mathrm{ha}^{-1}\right)$, nicosulfuron $\left(25 \mathrm{~g} \cdot \mathrm{ai} \cdot \mathrm{ha}^{-1}\right)$, nicosulfuron/rimsulfuron (25 g·ai $\cdot \mathrm{ha}^{-1}$ ), foramsulfuron (70 g·ai·ha ${ }^{-1}$ ), and primisulfuron/dicamba (166 g·ai $\cdot \mathrm{ha}^{-1}$ ) provide poor control of RR/LL volunteer corn. In summary, volunteer RR/LL corn can be a very aggressive competitor with hybrid RR/LL corn. Volunteer RR/LL corn should be controlled through diverse crop rotations rather than seeding continuous corn. Cultivation continues to be the only viable option to control volunteer RR/LL corn in hybrid RR/LL corn. Further studies are needed to evaluate new postemergence herbicide options to control volunteer RR/LL corn in hybrid RR/LL corn.

\section{Acknowledgements}

Funding for this project was provided in part by the Grain Farmers of Ontario (GFO) and the Can Advance program of the Agricultural Adaptation Council.

\section{References}

[1] Kulasekera, K. (2014) Grain Corn: Area and Production, by County. Ontario Ministry of Agriculture and Rural Affairs. http://www.omafra.gov.on.ca/english/stats/crops/estimate_new.htm\#metric

[2] Sikkema, P.H. and Soltani, N. (2007) Herbicide-Resistant Crops in Eastern Canada. In: Gulden, R.H. and Swanton, C.J., Eds., The First Decade of Herbicide-Resistant Crops in Canada. Topics in Canadian Weed Science, Sainte Anne de Bellevue, Quebec, 3-13.

[3] Sikkema, P.H., Robinson, D.E., Tardif, F.J., Lawton, M.B. and Soltani, N. (2013) Discovery of Glyphosate-Resistant Weeds in Ontario, Canada-Distribution plus Control. Global Herbicide Resistant Challenge Conference, Perth.

[4] Stahl, L., Potterand, B. and Gunsolus, J. (2013) Control Volunteer Corn for Yield Protection and Corn Rootworm Management. University of Minnesota Extension, 1-4. http://www.centrasota.com/pdf/agronomy/news/UM-Extension-VolunteerCornFactSheet-2013.pdf

[5] Deen, W., Hamill, A., Shropshire, C., Soltani, N. and Sikkema, P.H. (2006) Control of Volunteer Glyphosate-Resistant Corn (Zea mays) in Glyphosate-Resistant Soybean (Glycine max). Weed Technology, 20, 261-266. http://dx.doi.org/10.1614/WT-02-128.1

[6] De Corby, K.A., Van Acker, R.C., Brule-Babel, A.L. and Friesen, L.F. (2007) Emergence Timing and Recruitment of Volunteer Spring Wheat. Weed Science, 55, 60-69. http://dx.doi.org/10.1614/WS-06-102.1

[7] Lutman, P.J.W. and Dixon, F.L. (2008) The Competitive Effects of Volunteer Barley (Hordeumvulgare) on the Growth of Oilseed Rape (Brassica napus). Annals of Applied Biology, 117, 663-644.

[8] O’Donovan, J.T., Sharma, A.K., Kirkland, K.J. and de St. Remy, E.A. (1988) Volunteer Barley (Hordeumvulgare) Interference in Canola (Brassica campestris and B. napus). Weed Science, 36, 734-739.

[9] O’Donovan, J.T., Harker, K.N. and Dew, D.A. (2008) Effect of Density and Time of Removal of Volunteer Canola (Brassica rapa L.) on Yield Loss of Wheat (Triticumaestivum L.). Canadian Journal of Plant Science, 88, 839-842. http://dx.doi.org/10.4141/CJPS07204

[10] Bond, J.A. and Walker, T.W. (2009) Control of Volunteer Glyphosate-Resistant Soybean in Rice. Weed Technology, 23, 225-230. http://dx.doi.org/10.1614/WT-08-156.1

[11] Hall, M.R., Swanton, C.J. and Anderson, G.W. (1992) The Critical Period of Weed Control in Grain Corn. Weed Science, 40, 441-447.

[12] Knezevic, S.Z., Evans, S.P., Blankenship, E.E., Van Acker, R.C. and Lindquist, J.L. (2002) Critical Period for Weed Control: The Concept and Data Analysis. Weed Science, 50, 773-786. http://dx.doi.org/10.1614/0043-1745(2002)050[0773:CPFWCT]2.0.CO;2

[13] Page, E.R., Tollenaar, M., Lee, E.A. and Swanton, C.J. (2009) Does the Shade Avoidance Response Contribute to the Critical Period for Weed Control in Maize (Zeamays)? Weed Research, 49, 563-571. http://dx.doi.org/10.1111/j.1365-3180.2009.00735.x

[14] Liu, J.G., Mahoney, K.J., Sikkema, P.H. and Swanton, C.J. (2009) The Importance of Light Quality in Crop-Weed Competition. Weed Research, 49, 217-224. http://dx.doi.org/10.1111/j.1365-3180.2008.00687.x

[15] Alms, J., Moechnig, M., Deneke, D. and Vos, D. (2007) Competitive Ability of Volunteer Corn in Corn and Soybean. North Central Weed Science Society Proceedings, 62, 14. 
[16] Wilson, R., Sandell, L., Klein, R. and Bernards, M. (2010) Crop Production Clinic Proceedings. University of NELincoln Ext.

http://cpc.unl.edu/includes2010/pdf/VolunteerCornControl.pdf?exampleSessionId=1229904124000\&exampleUserLab el=Your\%20Name

[17] Stahl, L. and Coulter, J. (2012) Volunteer Corn-An Issue in Corn and Soybean. Minnesota Crop News. http://blog.lib.umn.edu/efans/cropnews/2012/05/volunteer-corn---an-issue-in-c.html

\section{Abbreviations}

LL: glufosinate resistant;

POST: postemergence;

RR: glyphosate resistant;

WAE: week after emergence. 